UDC 811.111'373.46'373.611

DOI https://doi.org/10.32999/ksu2663-3426/2020-2-2

\title{
WORD-FORMING SUFFIXES OF ENGLISH FRONTIER DEFENCE NOUN TERMS: PHONOLOGICAL AND SEMANTIC FEATURES
}

\author{
Yesypenko Nadiia Hryhorivna, \\ Doctor of Philological Sciences, Professor, \\ Head of the English Language Department \\ Yuriy Fedkovych Chernivtsi National University \\ n.yesypenko@chnu.edu.ua \\ orcid.org/0000-0002-6698-3201 \\ Yankovets Olena Volodymyrivna, \\ Postgraduate Student at the Department of Germanic, \\ General and Comparative Linguistics \\ Yuriy Fedkovych Chernivtsi National University \\ alena kaflevska@ukr.net \\ orcid.org/ 0000-0002-1323-8099
}

\begin{abstract}
Each part of speech is characterized by a specific set of affixes (suffixes and prefixes) that are used to form new words. Nominal terminological units are not an exception. The English frontier terms vocabulary is characterized by a considerable number of nominal lexemes. The coining of English frontier defence terms occurs according to standardized rules of English word formation. Terms containing no affixes are called primitives. Terms formed by adding a prefix, a suffix, or a prefix and a suffix are called derivatives. English frontier defence terms are characterized by the productive affixal way of word formation. Affixal method is a morphological way of word-formation. One of the most productive ways of noun-terms formation is the suffixal method (the prefixal method and the prefixal-suffixal method are less productive ones). In our article the phonological and semantic aspect of the suffixal way of word formation of English terms of the frontier sphere are considered. From the phonetic point of view, all suffixes are divided into those that cause a change in the stress of the derived lexeme, and those where the suffix has no effect on the stress. From the semantic point of view, a suffix has a semantic function and shows the belonging of a derivative to a specific lexical and semantic group. The meanings of a derived noun-term are the result of the interaction between the meaning of the suffix and that of the root. The semantic network of the nominal suffixes that form noun-terms of the frontier defence includes three multifaceted domains: ACTIVITY/ PROCESS, CHARACTERIZATION and AGENTHOOD within which the meanings of suffixes can be understood. Domains house noun-forming suffixes under one roof and single out their individual roles. The meaning of a suffix consists of the way it represents the facet within the domain. Each domain encompasses its own set of suffixes.
\end{abstract}

Key words: terminology, word-building, nominal suffix, semantic domain, productivity, stress.

\section{СЛОВОТВІРНІ СУФІКСИ АНГЛІЙСЬКИХ ТЕРМІНІВ ПРИКОРДОННОЇ СФЕРИ: ФОНЕТИЧНИЙ ТА СЕМАНТИЧНИЙ АСПЕКТ}

\author{
Єсипенко Надія Григорівна, \\ доктор фрілологічних наук, професор, \\ завідувач кафедри англійської мови \\ Чернівецький національний університет імені Юрія Федьковича \\ n.yesypenko@chnu.edu.ua \\ orcid.org/0000-0002-6698-3201
}

Янковець Олена Володимирівна,

аспірант кафедри германського, загального і порівняльного мовознавства

Чернівецький національний університет імені Юрія Федьковича

alena_kaflevska@ukr.net

orcid.org/0000-0002-1323-8099

Кожна частина мови характеризується певним набором афріксів (суфріксів та префріксів), які використовуються для утворення нових слів. Терміни-іменники не є винятком. У статті розглядаються номінативні словотвірні суфікси англійської термінології прикордонної сфери, а саме їх вплив на фонологічні та семантичні 
характеристики іменникових термінів. Є велика кількість визначень фрахових термінів. Англійський термін прикордонної сфрери трактується нами як штучно створена або запозичена із суміжної сфери лексична одиниця, або ж слово повсякденного вжитку у одному із його значень, яке володіє певними характеристиками, які дозволяють віднести його до термінів цього лексичного поля, а також взаємодіє із іншими термінологічними одинииями в межах даної терміносистеми. Англійський прикордонний вокабуляр характеризується великою кількістю іменників. Утворення англійських термінів прикордонної сфрери відбувається відповідно до стандартизованих правил англійського словотвору. Афріксація - це морфологічний спосіб словотворення. Терміни, які не містять афріксів, називаються примітивами. Терміни, утворені додаванням префрікса, суфрікса або префрікса та суфрікса, називаються похідними. Англійські терміни прикордонної сфрери характеризуються продуктивністю афріксального способу словотвору. Одним із найпродуктивніших способів утворення іменникових термінів є сусріксальний метод (префріксальний метод і префріксально-суфріксальний методи є менш продуктивними). Сутність суфріксального методу полягає у приєднанні суфріксів до кореня іменників, прикметників та дієслів і, як наслідок, утворення похідних лексем. У нашій статті розглядається фонологічний та семантичний аспект суфіксального способу словотвору англійських термінів прикордонної сфрери. 3 фонологічного погляду всі суфрікси поділяються на ті, які спричиняють зміну наголосу похідної лексеми, і ті, де суфрікс не має впливу на наголос. 3 семантичного погляду суфрікс виконує семантичну функцію і показує належність похідної до певної лексико-семантичної групи. Значення похідного терміна-іменника виникають в результаті взаємодії значення суфрікса і кореня. Семантична мережа іменних суфіксів, які утворюють іменні терміни прикордонної сфери, включає три різнопланові домени: ДІЯЛЬНІСТЬ / ПРОЦЕС, ХАРАКТЕРИСТИКА та ВИКОНАВЕЦЬ, в межах якИх значення суфріксів стає зрозумілим. Домени розміщують іменникові суфрікси в межах иієї сфрери вживання та виділяють їхні окремі ролі. Суффікс $є$ репрезентацією лексеми у межах цього домену. Кожен домен охоплює власний, властивий йому, набір суфріксів.

Ключові слова: термінологія, словотворення, іменний суфікс, семантичне поле, продуктивність, наголос.

\section{Introduction}

The terminological vocabulary occupies an important place in the vocabulary of the English language. Due to the rapid development of science, technology and all spheres of human life, there is an urgent need to determine, nominate and classify the lexemes which denote the relevant concepts. Over the past decades, English has become the predominant language for the transfer of specialized knowledge, which conditions the creation of new lexical units in other codes (Ibáñez \& \& Palacios 2014: 171). The nominal derivational suffixes were studied by Valerie Adams (Great Britain) (2001), Laurie Bauer (New Zealand) (2004), Jūratè Ruzaite (Lithuania) (2012), Mammadzade A.F. (Azerbaijan) (2013), Ingo Plag (Germany) (2018). The researchers view suffixes as one of the most productive means of noun-formation and outline the fact that nominal suffixes are often employed to derive abstract nouns from verbs, adjectives and nouns. Such abstract nouns can denote actions, results of actions, or other related concepts, as well as properties and qualities.

This paper gives an overview how English nounterms of the frontier defence sphere are formed. We focus on the morphological way of word-building, describing suffixation method in detail, and aim at investigating the most productive nominal suffixes.

The aim of the article is to analyse the peculiar features of functioning of the word-forming suffixes of English frontier defence noun terms, focusing on their phonological and semantic aspect.

\section{Terminology and term}

Alain Rey (1995) explains, that the initial motivation for the study of terminology was both spontaneous, like the motivation for technology, and theoretical, like the motivation behind the birth of science.
During the simultaneous expansion of knowledge and the growth of technology and communications in the eighteenth century, terminology was seen as a necessary tool for overcoming some of the difficulties associated with these multiple developments. Only in the twentieth century has terminology acquired a scientific orientation while at the same time being recognised as a socially important activity. An outstanding Spanish linguist, a professor of Terminology and Linguistics at the Universitat Pompeu Fabra (UPF) Teresa Cabre (1999: 1) defines terminology as "the discipline concerned with the study and compilation of specialized terms".

The definitions of a term differ which is explained by the fact that there are various approaches to the study of this issue. Theresa Cabre (1999: 113), studying the notion of term and its essence, claims that "terms are used to name a specialized reality and are thus different from words in the general language because they have a primarily referential purpose" (Cabre, 1999: 40).

In our work, we consider and analyse frontier defence terms and define them as units denoting frontier defence concepts that are created artificially, taken from a natural language or borrowed from related fields with which certain concepts correlate and which are correlated to other notions in this field. All of them form a terminological system.

\section{Word-formation in terminology}

In linguistics (particularly morphology and lexicology), word formation refers to the ways in which new words are made on the basis of other words or morphemes, also called derivational morphology. Word formation is a morphological, and sometimes grammatical, process that aims at producing words in a language. Word formation is a productive process in 
which words are created. According to A Dictionary of Linguistics and Phonetics (2008: 523) word formation is defined "as the whole process of morphological variation in the constitution of words, i.e. including the two main divisions of inflection and derivation.". There are five major morphological processes that affect roots and stems and which lead to the production of new words. Those processes are affixation, compounding, symbolism, reduplication and suppletion. Affixation consists in adding derivational affixes (i.e., prefixes, infixes and suffixes) to roots and stems to form new words (Zapata, 2007: 4). Affixation implies forming new lexemes through the derivational affixes and inflections.

In our research we consider the morphological type of word formation of frontier defence terminology, namely, the suffixal way of creating derived English noun-terms.

According to Ingo Plag, "Affix is a bound morpheme that attaches to bases (roots)" (Plag, 2018: 90). "Root is the central meaningful element of the word, to which affixes can attach" (Plag, 2018: 92). An affix is attached in order to build a new word or a variant of the same word. Affixes are bound because they cannot appear in isolation, but must combine with (be bound to) another morpheme to form a word. among bound morphemes, linguists distinguish inflectional from derivational morphemes. Derivational morphology deals with how distinct words are related to one another; inflectional morphology focuses on the different forms that a word may take, depending on its role in a sentence.

Derivational affixes derive new words by altering the definitional meaning or the grammatical category of a word, whereas inflectional affixes show grammatical relationships between words or grammatical contrast.

The essence of suffixation lies in combining the onomasiological stem suffix with the onomasiological trait in order to formally express the derivative belonging to a certain category (attribution, objectivity etc.) and a specific word-forming meaning. The word-forming meanings of the suffixes can vary within the onomasiological category by the semantic meaning of the derivatives they comprise. In other words, suffixation is the means of word formation with the help of suffixes. Suffixes usually modify the lexical meaning of the stem and can transfer words to a different part of speech. There are suffixes however, which do not shift words from one part of speech into another, but a suffix of this kind usually transfers a word into a different semantic group, e.g. a concrete noun becomes an abstract one. In Modern English, suffixation is characteristic of noun and adjective formation, while prefixation is characteristic of verb formation. The suffixal word formation of the terms is characterized by semantic changes, which are expressed by the addition of formal indicators - suffixes, which represent the main distinguishing features of the derived word. Although a suffix is not used independently, it has a semantic load that affects the new creation. The most productive noun suffixes in English, according to Ingo Plag (2018), are: -er, -ful, ion, -ist, -ism, -or, -ee, -an, -ian, -age, -ance, -ence, -ancy, -ency, -dom, -eer, -hood, -ship, -ment, -ness, -ce, -al, -ant, - ess, -ity, -cy, -ing.

The frontier defence terms' system is no exception to the use of suffixes as a way of word formation. The task of our study is to investigate the productive patterns of suffix word formation. Suffixes, being productive in creating frontier defence terms, are usually borrowed from general morphological fund. Some suffixes are found only in professional terms, and in general language they prove to be less typical (for example, suffix -ee: detainee and deportee). English frontier defence terms are a set of lexical units that have been extracted from reports of the European Border and Coast Guard Agency (Frontex) and the European Union Border Assistance Mission to Moldova and Ukraine (EUBAM), the Unified Training Program for Border and Coast Guard Basic Training in the EU (Common Core Curriculum), The US Coast Guardsman's Manual, and guidelines for observing fundamental rights of migrants and refugees at European airports, and the European Union Code on the rules governing the movement of persons across borders (Schengen Borders Code). The corpus of terms comprises 1430 units, 187 were the nouns, formed by means of suffixation.

We identified 34 suffix morphemes, with the help of which 187 noun terms have been formed. Some suffixes show up to be more productive than others. Productivity is usually defined with respect to the extent to which a morpheme is expected to appear in novel forms. The suffixes, which are most productive in forming nominal terms under consideration, are illustrated in figure 1.

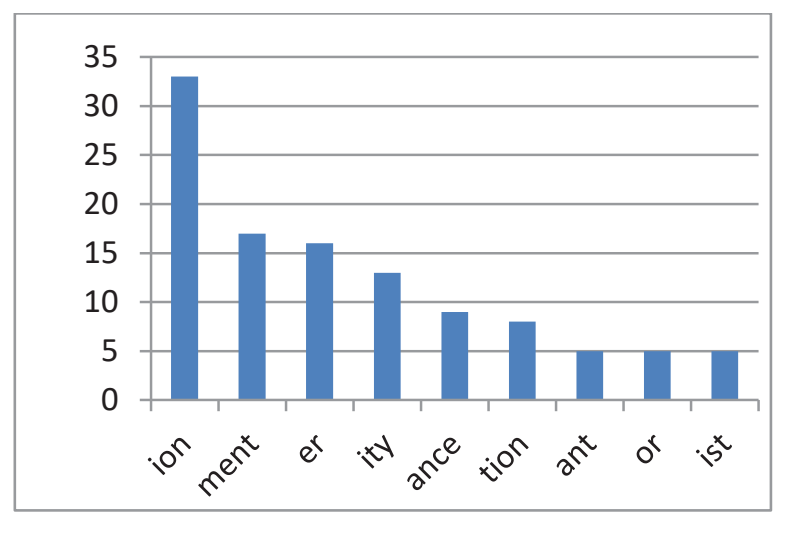

Figure 1. Productivity of word-forming nominal suffixes within the frontier defence terminological system 
Judging by the data, presented in the diagram, we can conclude, that the most productive noun-forming suffix is -ion, which is used 33 times while forming derived frontier defence nominal terms $(18 \%$ of all the terms within our research). The suffixes -ent (resident), -on (comparison), -ory (territory), -ary (itinerary), -ics (electronics), -ise (expertise), -dom ( freedom), -ia (guardia), -ship (leadership), -ery (machinery), -ce (offence), -cy (consistency), -ry (ministry), -ue (technique), -ial (official) are used one time each. Thus, in the corpus under study these morphemes are less productive in forming frontier defence noun terms.

\section{Phonological features of nominal suffixes}

Ingo Plag (2018: 98) in his research on wordformation outlines the fact that affixes possess particular properties: "Dealing with these general properties before looking at individual affixes has the considerable advantage that certain properties of affixes need not be stated for each affix individually, because, as we will see, these properties are at least partially predictable on the basis of other properties that a given affix shares with certain other affixes. These properties are mostly of a phonological nature, but they have serious consequences for the properties of derived words and the combinability of affixes with roots and other affixes".

He divides suffixes into two categories: the ones that trigger alternations and the ones that do not (Plag, 2018: 101). Phonological analysis of the derived nouns of the frontier defence terminology proved that such nominal suffixes as -(at)ion, -ize (ise), -ee, -ian can cause the shift of stress: mobilize $<$ mobilization, expert $<$ expertise, detain $<$ detainee, tẹchnic $<$ technician.

The derived noun-terms display a phonological form with a shifted stress pattern that conditions a first syllable stress to be moved to an affix bearing syllable.

The noun-forming suffixes -ment, -dom, -ness, -ship, -son do not change a stress pattern in the base and the derived noun: endorse < endorsement, free $<$ freedom, bussy < business, leader <leadership.

Our finding on phonological features of nounforming suffixes in the frontier defence terminology comply with the research results of Plag (2018), that vowel-initial suffixes have a strong tendency to trigger alternations, whereas consonant-initials have a strong tendency not to trigger alternations.

\section{Semantic features of word-forming suffixes}

Nominal suffixes in English frontier defence terminology bear certain meanings by which terms acquire certain semantic features. The meanings of a derived noun-term emerge as a result of the interaction between the meaning of the suffix and that of the root. The noun-forming suffix is a bound morpheme which is added to the end of a free morpheme to form a noun. When the frontier defence derived nouns are concerned, the free morpheme is a verb, an adjective and a noun. When the root is a verb, the nounterm formed is either an agent or an action. The root represented by an adjective brings characterization into the meaning of a noun-term. The nominal roots indicate an agent. The noun-forming suffixes within the frontier defence terms' system yield some prototypical semantic properties allowing us to elaborate the semantic network of the nominal suffixes under study. The network consists of domains, knowledge structures which comprise a set of suffixes. Within the domains the nominal suffixes occupy different facets, which symbolize a particular notion:

Domain: ACTION OR PROCESS IN THE FIELD OF FRONTIER DEFENCE

The suffixes -tion,-ion indicate action in a process. They convey the sense of the act of doing the process referred to in the root. For example, confirm < confirmation, deport $<$ deportation. The suffix $-i s m$ added to the nominal root features the sense of the practice based on the thing named by the root. For example, terrorism is the practice of using violent actions, (evaluation) mechanism is the process is a peer review process that measures the progress of the actions, specified in Regulation (EU), tourism is the process of spending time away from home.

Domain: PROFESSION IN THE FIELD OF FRONTIER GUARDING AND DEFENCE; THE PERFORMER (HUMAN AND NON-HUMAN) OF A PARTICULAR ACTION RELATED TO THE FRONTIER DEFENCE

The suffixes-er and-or are indicators (a) of human agenthood (a person who performs the action labelled in the root). This sense appears from the verbal root. For example, a commander is an officer who is in charge of a military operation, a trafficker is a person who delivers or sells illegal goods (b) of non-human agenthood (a thing that is set to perform the action labelled by the root). For example, a scanner is a device that is used to see inside the luggage, a navigator is an instrument or device which assists in navigating a vessel or aircraft. The suffix -ist symbolizes agenthood: a person who performs the action signified by the root. For example, a terrorist is a person who uses terrorism in the pursuit of political aims, a separatist is a person who supports the separation of a particular group of people from a larger body on the basis of ethnicity. Domain: activities or processes taking place at the border.

Processes in the frontier defence incorporate two main components: action and result. The action refers to anything that one does in order to deal with or achieve a result. For example, emboss < embossing, cross $<$ crossing, thus, the suffix -ing shows the action. 
The result stems from the action. The suffix -ment illustrates result in a process. It has a semantic feature of the result of the process referred to by the root. For example, endorsement is the act or result of endorsing someone or something at the border, assessment is the result of documents (or travellers) being assessed. The suffixes -ment and -ing capture an action that one takes to achieve or the result gained by the action.

Domain: QUALITY / FEATURE (OF ENTITIES RELATING TO THE FRONTIER DEFENCE); CONDITIONS (OF CARRYING OUT DEFENCE ACTIVITIES)

The suffixes -ity, $-t y$ are indicative of characterization. They show (a) the quality or property designated by the root (an adjective). For example, hostility is the quality of being hostile. The feature expressed in this noun-term reveals an apparent characteristic that is readily felt or clearly understood. Hostility subsumes the state or quality of entities involved in the frontier defence; (b) the mode of dealing with the situation designated by the root. This sense arises when the adjectival roots are qualitative and form abstract noun-terms. For example, legality is the mode of being legal. The feature embodied in this term is inherent that forms a permanent element of the frontier defence entity. Other examples are authentic $<$ authenticity, integral < integrity. The suffix -ness indicates the property denoted by the root (an adjective). This sense surfaces when the adjectival roots are qualitative and form noun-terms applying to non-humans. For example, (physical) fitness is the property of being fit (which is one of the main requirements for a frontier officer). Other derivations are effective $<$ effectiveness (the property of frontier defence officers' legal actions being effective), ready $<$ readiness (the property of being immediate while dealing with frontier challenges).

Domain: STATUS OR STATE RELATED TO THE FRONTIER DEFENCE

The suffixes -(an)ce and -(en)ce have two semantic niceties: (a) the state referred to in the root. For example, allow $<$ allowance, comply $<$ compliance. Here, the suffixes indicate the status that the frontier defence entity reaches; (b) the act of doing the process referred to in the root. For example, maintenance is the act of keeping the border in proper condition. Other derivations are issue < issuance, observe observance.

Domain: CIVIL PEOPLE CROSSING THE BORDER

The suffixes -ant, -ent form agent nouns. For example, migrate < migrant, reside < resident . These suffixes mean a person who performs a specific action signalled by the root. By contrast, in its function the suffix $-e e$ is an illuminator of patientivity. In the frontier defence terminology, it has a semantic specification of a person to whom something is transferred by the action named by the root, for example, detain < detainee. The suffix -ee derives nounterms which refer to performers of actual actions, for example, refuge < refugee.

Consequently, nominal suffixes of the frontier defence terminology evoke various semantic properties of the derived noun-terms. The meanings of the terms are best demarcated by domains, that are knowledge structures within which the meanings of suffixes can be understood. The constructed domains of meanings of the derived noun-terms prove the semantic relations among the elements of a derivational paradigm. The connection between a derivational paradigm and a cognitive category (a knowledge structure) is discussed by Pavol Stekauer (2014: 354): The derivational paradigm rests on the cognitive category of, for example, RESULT OF ACTION (which may, in English, be formally represented by several prefixes and suffixes). [...] one can speak about several distinct derivational paradigms within the category of AGENT, defined by the relation of a verbal base and the suffix -er; nominal base and the suffix -ist; nominal base and the suffix-ian; verbal base and the suffix -ee; etc. The undertaken analysis revealed several domains evoked by nounforming suffixes of the border defence area: activity/ process, characterization and agenthood. Domains are important as they house noun-forming suffixes under one roof and single out their individual roles. The meaning of a suffix consists of the way it represents the facet within the domain. The domain of activity/process is symbolized by the nominal suffixes -tion /-ion, -ism and -ment; the domain of characterization is illustrated by the noun-forming suffixes -ity, -ty, -ness, -(an)ce and -(en)ce; the domain of agenthood is manifested by the nominal suffixes -ant, -ent, -ee, -er/-or, -ist.

\section{Conclusions}

In this paper we indicated some features of suffixation in the process of nouns formation in the English frontier defence terminology. We outlined general possible ways of word-formation in the English language. The discussion of the ways of word formation in English has shown suffixation as one of the productive morphological ways of word-formation. It is a way of creating new terms at the expense of internal resources; formation of derivative words (derivatives) from existing terms or from new lexical units.

Suffixation is a highly productive means of English frontier defence terms formation. Derivational suffixes of noun-terms vary in the productivity. The suffixes -ion, -ment and -er are marked by the highest productivity within the terminological system under study.

The interesting phenomenon of nominal suffixes to change a stress pattern in the derived noun-terms 
does not call this conclusion into question as vowel-initial suffixes have a strong tendency to trigger alternations in the English language.

The semantic network of the nominal suffixes that form noun-terms of the frontier defence includes three multifaceted domains. The domain of activity/process is symbolized by the nominal suffixes -tion /-ion, -ism and -ment that activate different facets. The domain of characterization describes the character of entities, be it animate or inanimate, related to the frontier defence. This domain is manifested by the nominal suffixes -ity, -ty, -ness, -(an)ce and -(en)ce, which differ in highlighting distinct features of guarding the border. The domain of agenthood marks a person, a thing or a role played by them in the frontier defence. It is about a person or a thing that performs a particular action while providing security at the border or specialises in a particular area in the frontier defence. The domain agenthood is earmarked by the agentforming suffixes -ant, -ent, -ee, -er/-or, -ist. These suffixes derive noun-terms which refer to performers of potential technical/non-technical actions (e.g. scanner, reservist) or actual actions (e.g. refugee).

\section{BIBLIOGRAPHY:}

1. Adams V. Complex Words in English. Harlow: Pearson Education/Longman, 2001. $184 \mathrm{p}$.

2. Annual Report. 1 December 2012 - 30 November 2013. European Union Border Assistance Mission to Moldova and Ukraine. URL: http://eubam.org/wp-content/ uploads/2015/11/Report_2013_ENGL-.pdf (date access: 01.10.2019).

3. Bauer L. The Function of Word-Formation and the Inflection-Derivation Distinction. In Henk Aertsen, Mike Hannay \& Rod Lyall (eds), Words in their Places. A Festschrift for J. Lachlan Mackenzie. Amsterdam: Vrije Universiteit, 2004. P. 283-292.

4. Cabré T. M. Terminology: Theory, Methods, and Applications. Ed. Juan C. Sager. Transl. Janet Ann DeCesaris. Amsterdam: John Benjamins Publishing, 1999. 248 p.

5. Crystal D. A Dictionary of Linguistics and Phonetics (6th ed.). Oxford: Blackwell, 2008. 529 p. URL: https://www. academia.edu/23349059/A_Dictionary_of_Linguistics_ and_Phonetics_David_Crystal (date access: 01.10.2019).

6. Frontex. Common Core Curriculum. EU Border Guard Basic Training. Warsaw : Frontex, 2017. 347 p.

7. Fundamental Rights at Airports: Border Checks at Five International Airports in the European Union. Luxembourg: Publications office of the European Union, 2014. 124 p.

8. Ibáñez M. S., Palacios J. G. Semantic characterization of terms as a trace of terminological dependency. In Pamela Faber and Marie-Claude L'Homme (ed.). Terminology. International Journal of Theoretical and Applied Issues in Specialized Communication. 2014. Volume 20, Issue 2. P. 171-197.

9. Krietemeyer G. E. The Coast Guardsman's Manual. Revised by George E. Krietemeyer, with the assistance of Doug Starr and Wayne Truax. 8th ed. Naval Institute Press, 1991. $736 \mathrm{p}$.
10. Mammadzade A. F. Lexical Features of English Military Discourse. Bulletin of Zaporizhzhia University. Philological Sciences. 2013. 1. P. 139-141.

11. Plag I. Word-Formation in English (2nd edition). Cambridge : Cambridge University Press, 2018. 246 p.

12. Regulation (EU) $2016 / 399$ of the European Parliament and of the Council of 9 March 2016 on a Union Code on the rules governing the movement of persons across borders (Schengen Borders Code), OJ L 77, 23.3.2016. P. 1-52.

13. Rey A. Essays on Terminology. Translated and edited by Juan C. Sager. Amsterdam \& Philadelphia: John Benjamins, 1995. 223 p.

14. Ruzaitè J. Studying Word-Formation in English. A Resource Book. Kaunas: Vytautas Magnus University Publishing House, 2012. 80 p. URL: https://www.vdu.It/ cris/bitstream/20.500.12259/228/1/ISBN9789955128021. pdf (date access: 01.10.2019).

15. Stekauer P. Derivational paradigms. In Rochelle Lieber and Pavol Stekauer (ed.). The Oxford Handbook of Derivational Morphology. Oxford: Oxford University Press, 2014. P. 354-370.

16. Zapata A. A. Types of Words and Word-Formation Processes in English. 2007. URL: https://www.academia. edu/5049589/Ingl\%C3\%A9s_IV_B-2007_Unit_1_Types_ of_Words_and_Word_Formation_Processes_in_English (date access: 01.10.2019).

\section{REFERENCES:}

1. Adams, Valerie. (2001). Complex Words in English. Harlow: Pearson Education/Longman. DOI: 10.1017/ S1360674303211060.

2. Annual Report. 1 December 2012 - 30 November 2013. European Union Border Assistance Mission to Moldova and Ukraine. Retrieved from http://eubam.org/wp-content/ uploads/2015/11/ Report_2013_ENGL-.pdf.

3. Bauer, Laurie. (2004). The Function of Word-Formation and the Inflection-Derivation Distinction. In Henk Aertsen, Mike Hannay \& Rod Lyall (eds), Words in their Places. A Festschrift for J. Lachlan Mackenzie. 283-292. Amsterdam: Vrije Universiteit.

4. Cabré, Teresa M. (1999). Terminology: Theory, Methods, and Applications. Ed. Juan C. Sager. Transl. Janet Ann DeCesaris. Amsterdam: John Benjamins Publishing. DOI: 10.7202/004006ar.

5. Crystal, D. (2008). A Dictionary of Linguistics and Phonetics (6th ed.). Oxford: Blackwell.

6. Frontex. Common Core Curriculum. EU Border Guard Basic Training. (2017). Warsaw: Frontex. DOI:10.2819/829367.

7. Fundamental Rights at Airports: Border Checks at Five International Airports in the European Union. (2014). Luxembourg: Publications office of the European Union. DOI:10.2811/68358.

8. Ibáñez, Miguel Sánchez \& Palacios, Joaquín García. (2014). Semantic characterization of terms as a trace of terminological dependency. In Pamela Faber and Marie-Claude L'Homme (ed.). Terminology. International Journal of Theoretical and Applied Issues in Specialized Communication. Volume 20, Issue 2. 171-197.

9. Krietemeyer, George E. (1991). The Coast Guardsman's Manual. Revised by George E. Krietemeyer, with the assistance of Doug Starr and Wayne Truax. 8th ed. Naval Institute Press. ISBN13: 9781557504500. 
10. Mammadzade, A. F. (2013). Lexical Features of English Military Discourse. Bulletin of Zaporizhzhia University. Philological Sciences. 1. 139-141.

11. Plag, Ingo. (2018). Word-Formation in English (2nd edition). Cambridge: Cambridge University Press. DOI: $10.1017 / 9781316771402$.

12. Regulation (EU) $2016 / 399$ of the European Parliament and of the Council of 9 March 2016 on a Union Code on the rules governing the movement of persons across borders (Schengen Borders Code), OJ L 77, 23.3.2016, p. 1-52.

13. Rey, Alain. (1995). Essays on Terminology. Translated and edited by Juan C. Sager. Amsterdam \& Philadelphia: John Benjamins.
14. Ruzaitè, Jūratè. (2012). Studying Word-Formation in English. A Resource Book. Kaunas: Vytautas Magnus University Publishing House. ISBN 978-9955-12-801-4.

15. Stekauer, Pavol. (2014). Derivational paradigms. In Rochelle Lieber and Pavol Stekauer (ed.). The Oxford Handbook of Derivational Morphology. Oxford : Oxford University Press. 354-370.

16. Zapata, Argenis A. (2007). Types of Words and WordFormation Processes in English. Retrieved from https://www.academia.edu/5049589/Ingl\%C3\%A9s_ IV_B-2007_Unit_1_Types_of_Words_and_Word_ Formation_Processes_in_English.

Стаття надійшла до редакиї 16.09.2020. The article was received September 9, 2020. 